\title{
Protein and energy utilization in germ-free and conventional chicks given diets containing different levels of dietary protein
}

\author{
BY M. FURUSE AND H. YOKOTA \\ Laboratory of Animal Nutrition, School of Agriculture, Nagoya University, Chikusa-ku, \\ Nagoya 464, Japan
}

(Received 6 June 1983 - Accepted 3 October 1983)

1. The present study was done to clarify the relationship between the amount of dietary protein given to, and the gut microflora of, the host. Day-old chicks were given diets containing three concentrations of dietary protein $(50,200$ and $400 \mathrm{~g} / \mathrm{kg})$ for $14 \mathrm{~d}$. Body-weight gain, food consumption, body consumption, and protein and energy utilization were measured.

2. There was no difference in body-weight gain and food consumption between germ-free (GF) and conventional (CV) chicks, but food conversion efficiency ( $\mathrm{g}$ body-weight gained $/ \mathrm{g}$ food consumed) was significantly higher in $\mathrm{GF}$ than in CV chicks.

3. Little difference was found in protein retention ( $g$ protein retained $/ 14 \mathrm{~d}$ ), but protein retention rate ( $\mathrm{g}$ protein retained/g protein consumed) tended to be higher in GF chicks, particularly those given the diet with the lowest protein.

4. The presence of micro-organisms improved metabolizable energy (ME) values of the diets, but not all of the digested energy in $\mathrm{CV}$ chicks was utilized for growth. Therefore there was little difference in energy retention (kJ energy retained $/ 14 \mathrm{~d}$ ) between environments, although energy retention rate ( $\mathrm{kJ}$ energy retained/kJ $\mathrm{ME}$ consumed) was significantly lower in CV chicks. The amount of body fat in GF chicks was higher than that in CV chicks, especially in those fed on the low-protein diet.

5. It is suggested that although the gut microflora may have beneficial effects on the digestion of dietary energy components, they may have detrimental effects on utilization of ME by their hosts, because chicks harbouring a gut microflora seem to have higher energy requirements for maintenance.

It is well known that enzymes produced by gut micro-organisms (e.g. proteases, decarboxylases, transaminases and oxidases) may have some influence on digestion and metabolism of dietary proteins, and the possible effects on the host have been discussed. For example, amino acids might be released from a poorly digestible protein through the action of microbial proteases (Coates et al. 1972); ammonia formed from urea by the action of bacterial urease could be used by the host for synthesis of non-essential amino acids (Okumura et al. 1976). These activities could be beneficial to the host. Conversely, microbial catabolism of amino acids or incorporation of amino acids into microbial proteins would be detrimental to the host (Salter, 1973).

In a study of energy metabolism, Levenson \& Tennant (1963) reported that germ-free (GF) rats had a lower metabolic rate than their conventional (CV) counterparts. Hegde et al. (1982) found that metabolizable energy (ME) values of diets containing wheat straw were higher in CV than in GF birds, and suggested that the CV birds obtained a small amount of energy from dietary fibre.

The present study was designed to investigate the influence of the gut microflora on the protein and energy utilization of diets in chicks.

\section{MATERIALS AND METHODS}

Chicks

Single comb, White Leghorn chicks of mixed sexes were used, the parents of which $\left(\sigma^{\star}:\right.$ strain no. 09, : : strain no. 18) were brought from Gifu Prefectural Poultry Breeding Station in Japan. The experimental eggs were incubated in a commercial incubator for $18 \mathrm{~d}$, then they were candled and disinfected by spraying with peracetic acid solution $(20 \mathrm{~g} / 1)$. Some of the 
Table 1. Composition $(\mathrm{g} / \mathrm{kg})$ of experimental diets

\begin{tabular}{|c|c|c|c|}
\hline \multirow[b]{2}{*}{ Ingredients } & \multicolumn{3}{|c|}{ Protein content $(\mathrm{g} / \mathrm{kg})$} \\
\hline & 50 & 200 & 400 \\
\hline Soya-bean protein isolate* & $62 \cdot 5$ & 250 & 500 \\
\hline Sucrose & 200 & 200 & 200 \\
\hline Maize oil & 50 & 50 & 50 \\
\hline Cellulose $\dagger$ & 30 & 30 & 30 \\
\hline Glycine & 0.625 & $2 \cdot 5$ & 5 \\
\hline L-Methionine & 1.25 & 5 & 10 \\
\hline Mineral mixture $\ddagger$ & 60 & 60 & 60 \\
\hline Vitamin mixture + & 4 & 4 & 4 \\
\hline Choline chloride & 1.5 & 1.5 & 1.5 \\
\hline Inositol & 1 & $i$ & $i$ \\
\hline Maize starch & to 1000 & to 1000 & to 1000 \\
\hline $\begin{array}{l}\text { Chemical analysis (crude } \\
\text { protein }(\mathrm{N} \times 6 \cdot 25) / \mathrm{kg})\end{array}$ & $59 \cdot 1$ & $215 \cdot 3$ & $425 \cdot 9$ \\
\hline
\end{tabular}

* Fujipro-R, Fuji oil Co. Ltd, Osaka, Japan.

$\dagger$ Pulpflock W-1, Sanyo Kokusaku Pulp Co. Ltd, Tokyo, Japan.

\$ Salter et al. (1974).

eggs were introduced into plastic isolators and the incubation was continued. The remainder were replaced in the incubator to hatch. Chicks were distributed to stainless-steel metabolism cages with wire screen floors, two to a cage, so that the mean initial body-weight per cage was as nearly as possible the same between isolators and between GF and CV environments. $\mathrm{CV}$ chicks were reared in similar cages in a conventional room. There was free access to diets and water throughout.

\section{Diets}

Diets containing three concentrations of dietary protein were used. Diet 1 (a low-protein diet, LD) contained $50 \mathrm{~g}$ crude protein $/ \mathrm{kg}$; diet 2 (an adequate-protein diet, AD), $200 \mathrm{~g}$ crude protein $/ \mathrm{kg}$; diet 3 (a high-protein diet, HD), $400 \mathrm{~g}$ crude protein $/ \mathrm{kg}$. The compositions of the diets are given in Table 1. After mixing all ingredients, the diets were granulated, placed in plastic bags and irradiated at $5 \mathrm{Mrad}$ from a ${ }^{60} \mathrm{Co}$ source. Water-soluble vitamins were increased to four times normal levels to meet possible losses during the sterilization process (Coates et al. 1969). The sterilized diets were given to the CV birds as well as to the GF birds.

\section{Experimental procedure}

The droppings from each pair of chicks were collected from day 10 to day 14 into $100 \mathrm{ml}$ hydrochloric acid $(5 \mathrm{ml} / \mathrm{l})$ in deep, stainless-steel trays beneath the metabolism cages. The acid was used to prevent further microbial action in droppings from $\mathrm{CV}$ chicks and to avoid loss of ammonia. Droppings were air-dried at $55^{\circ}$ and ground for analysis.

At day 14 , chicks were killed by cervical dislocation and frozen at $-20^{\circ}$. The frozen carcasses were minced with a meat grinder. The mince was frozen again with solid carbon dioxide, minced for a second time and dried at $55^{\circ}$ for $48 \mathrm{~h}$. Nitrogen in the diets, droppings and carcasses was determined by the Kjeldahl procedure (Kjel-Foss Automatic 16210, A/S N. Foss Electric, Denmark). Protein contents in diets and carcasses were defined as $\mathrm{N} \times 6 \cdot 25$. Fat contents in carcasses were extracted overnight (about $16 \mathrm{~h}$ ) with diethyl ether 
using a Soxhlet apparatus and determined gravimetrically. Water in the carcasses was determined gravimetrically by drying the mince at $135^{\circ}$ for $2 \mathrm{~h}$ and weighing the residue. Gains in protein and energy over the experimental period were determined by subtracting the initial from the final values for body composition. At the beginning of the feeding period (day 0), four chicks were killed to determine the initial body composition. They contained $128.5 \mathrm{~g}$ protein $/ \mathrm{kg}$ body-weight and $64.2 \mathrm{~g}$ fat $/ \mathrm{kg}$ body-weight. Energy content of the chick was calculated using the values of 39.12 and $23.68 \mathrm{~kJ} / \mathrm{g}$ for fat and protein in the body respectively (Fraps, 1946). The energy contents of diets and droppings were measured with an automatic bomb calorimeter (Shimadzu CA-3, Shimadzu Co., Kyoto, Japan). ME values were corrected to a condition of $\mathrm{N}$ equilibrium (Hill \& Anderson, 1958), then ME intake for $14 \mathrm{~d}$ was calculated.

\section{Sterility checks}

Sterility tests were undertaken at day 4 and day 12 . Three liquid media (trypticase soy broth, thioglycollate medium without indicator-135C (BBL, Cockeysville, Maryland 21030, USA) and sabouraud liquid medium (Oxoid Ltd, Basingstoke, Hants) and two agar plates (tryptone soya agar (Oxoid Ltd) and tryptone soya agar plus yeast extract (BBL)) were used. Liquid media were used to detect aerobes, and agar plates were used to determine both aerobes and anaerobes. The birds were judged to be germ-free only when all these tests were negative for 2 weeks.

\section{Statistical analysis}

Data were subjected to analysis of variance and Student's $t$ test. Body-weight gain, body composition, protein and energy retention were calculated on a per-bird basis, and food consumption, food conversion efficiency, protein retention rate, energy retention rate, $\mathrm{ME}$ value and ME intake were calculated on a per-cage basis. The numbers of birds tested were, GF:LD 10, AD 10, HD 8; CV:LD 8, AD 10, HD 8. The number of cages tested was half the number of birds. The treatment sums of squares for the main effect of protein content and the interaction between protein content and environment were split into linear and quadratic terms.

\section{RESULTS}

Body-weight gain, food consumption and food conversion efficiency of GF and CV chicks Table 2 shows body-weight gain, food consumption and food conversion efficiency ( $\mathrm{g}$ body-weight gain/g food consumed) of chicks given diets containing three different amounts of protein for $14 \mathrm{~d}$. Both body-weight gain and food consumption were increased curvilinearly with significant linear $(P<0.01)$ and quadratic $(P<0.01$ or $P<0.05)$ effects as the dietary protein increased. There was, however, no significant difference between GF and $\mathrm{CV}$ chicks. Food conversion efficiency was increased curvilinearly with significant linear $(P<0.01)$ and quadratic $(P<0.01)$ effects as the dietary protein increased, and it was significantly higher in GF than in CV chicks.

\section{Body composition of $G F$ and $C V$ chicks}

The body compositions of GF and CV chicks are listed in Table 3. Body fat decreased curvilinearly with significant linear $(P<0.01)$ and quadratic $(P<0.01)$ effects, and body protein and water contents increased curvilinearly with significant linear and quadratic effects as the dietary protein increased. A significant interaction was found between environments and the quadratic term of dietary protein in body fat and water contents, implying that body fat readily accumulated in GF birds given the low-protein diet. 
M. FURUSE AND H. YoKota

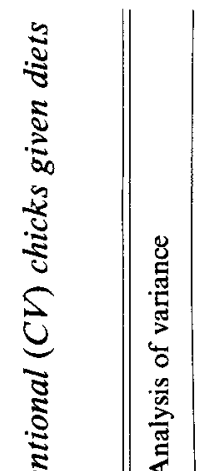

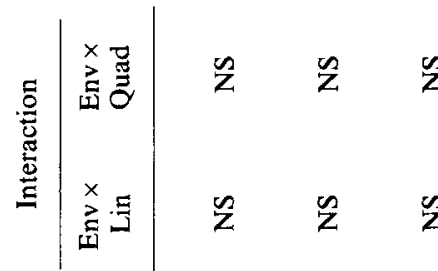

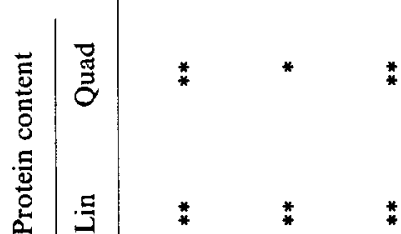

盖㔯学:

$\dot{0}$
$\dot{0}$
$\dot{a}$
$*$
$\ddot{\ddot{o}}$
$\dot{0}$
$v$

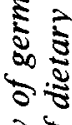

ลे

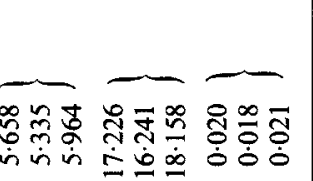

乙

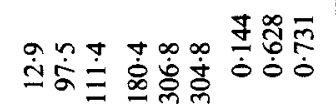
政

نํํㅇ

牙

.

焉岂

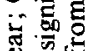
寻它 产皆 要要 焉窇 焉的 
Table 3. The body composition ( $\mathrm{g} / \mathrm{kg}$ body-weight) of germ-free (GF) and conventional (CV) chicks given diets containing different amounts of dietary protein

\begin{tabular}{|c|c|c|c|c|c|c|c|c|c|}
\hline & \multirow[b]{3}{*}{$\begin{array}{l}\text { Protein } \\
\text { (g/kg diet })\end{array}$} & \multirow[b]{3}{*}{ GF } & \multirow[b]{3}{*}{$\mathrm{CV}$} & \multirow[b]{3}{*}{ SED } & \multicolumn{5}{|c|}{ Analysis of variance } \\
\hline & & & & & \multirow[b]{2}{*}{ Env } & & \multicolumn{2}{|c|}{ Interaction } \\
\hline & & & & & & Lin & Quad & $\begin{array}{c}\text { Env } x \\
\text { Lin }\end{array}$ & $\begin{array}{l}\text { Env } \times \\
\text { Quad }\end{array}$ \\
\hline Body fat (df 45) & $\begin{array}{r}50 \\
200 \\
400\end{array}$ & $\begin{array}{r}197.1 \\
111.0 \\
86.8\end{array}$ & $\begin{array}{l}138 \cdot 3^{* * 1} \\
110 \cdot 0 \\
77 \cdot 8\end{array}$ & $\left.\begin{array}{l}8 \cdot 19 \\
7 \cdot 72 \\
8 \cdot 63\end{array}\right\}$ & $* *$ & $* *$ & ** & $* *$ & $* *$ \\
\hline Body protein (df 18$) \dagger$ & $\begin{array}{r}50 \\
200 \\
400\end{array}$ & $\begin{array}{l}152 \cdot 0 \\
191 \cdot 0 \\
200 \cdot 3\end{array}$ & $\begin{array}{l}157.9 \\
191.6 \\
200.9\end{array}$ & $\left.\begin{array}{l}3.26 \\
3.07 \\
3.44\end{array}\right\}$ & NS & $* *$ & $* *$ & NS & NS \\
\hline Body water (df 45) & $\begin{array}{r}50 \\
200 \\
400\end{array}$ & $\begin{array}{l}617 \cdot 6 \\
672 \cdot 9 \\
693 \cdot 2\end{array}$ & $\begin{array}{l}672 \cdot 5^{* * 1} \\
678 \cdot 1 \\
695 \cdot 1\end{array}$ & $\left.\begin{array}{l}8.54 \\
8.06 \\
9 \cdot 01\end{array}\right\}$ & $* *$ & $* *$ & $*$ & $* *$ & $*$ \\
\hline
\end{tabular}

Env, Environment; Lin, linear; Quad, quadratic.

Significance levels: NS, not significant, $P>0.05 ;{ }^{*} P<0.05 ; * * P<0.01$.

$\dagger$ Degrees of freedom reduced to 18 due to evidence of variance heterogeneity.

1 Significance of difference from GF values.

\section{Protein utilization by GF and CV chicks}

Table 4 shows protein retention (g protein retained/14 d) and protein retention rate $(\mathrm{g}$ protein retained/g protein consumed), which were calculated from the results of carcass analysis. Protein retention increased curvilinearly with significant linear $(P<0.01)$ and quadratic $(P<0.01)$ effects as the dietary protein increased, but there was no significant difference between environments. The AD gave the highest retention rate. In general, the protein retention rate tended to be higher in GF chicks, and the difference was significant on the LD.

\section{Energy utilization by $G F$ and $C V$ chicks}

$\mathrm{N}$-corrected ME, ME intake ( $\mathrm{kJ} / 2$ birds per $14 \mathrm{~d}$ ), energy retention ( $\mathrm{kJ}$ energy retained $/ 14 \mathrm{~d}$ ) and energy retention rate ( $\mathrm{kJ}$ energy retained/ $\mathrm{kJ}$ ME consumed) are given in Table 5 . $\mathrm{N}$-corrected ME was hardly influenced by dietary protein content. However, it was significantly higher in $\mathrm{CV}$ than in GF chicks $(P<0.05)$. Energy retention showed a curvilinear change with significant linear $(P<0.01)$ and quadratic $(P<0.01)$ effects, and it was caused by changes in the dietary protein contents. A significant intereaction was found between environments and the quadratic term of protein content. Mean energy retention was almost the same between environments but, on the LD, GF chicks accumulated significantly more energy than CV chicks. Energy retention rate was also changed curvilinearly with significant linear $(P<0.01)$ and quadratic $(P<0.01)$ effects as the dietary protein contents increased. A significant interaction was found between environments and the quadratic term of protein content at $P<0.05$. Mean energy retention rate in the GF environment was significantly higher than that in the CV state.

\section{Calculation of energy costs of deposition of fat and protein}

The energy retention rate was significantly higher, implying that utilization of energy was higher in GF than in CV chicks. Partitioning energy intake by multiple regression analysis 


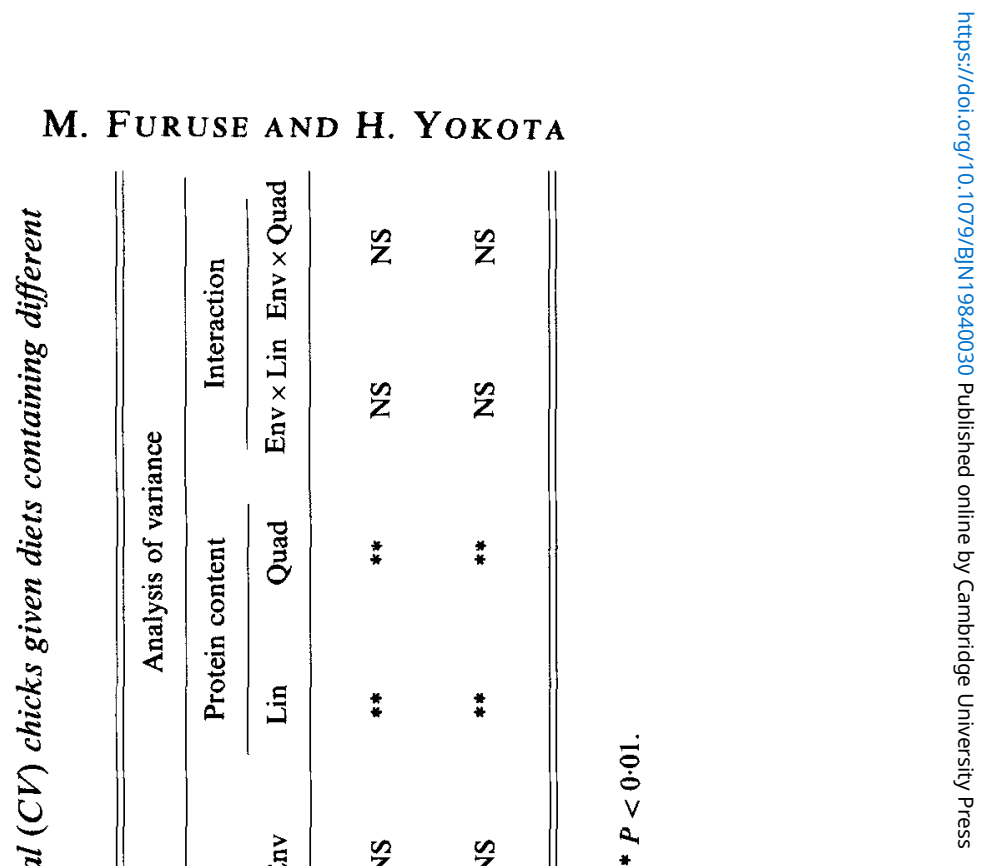


Gut flora and energy utilization in chicks

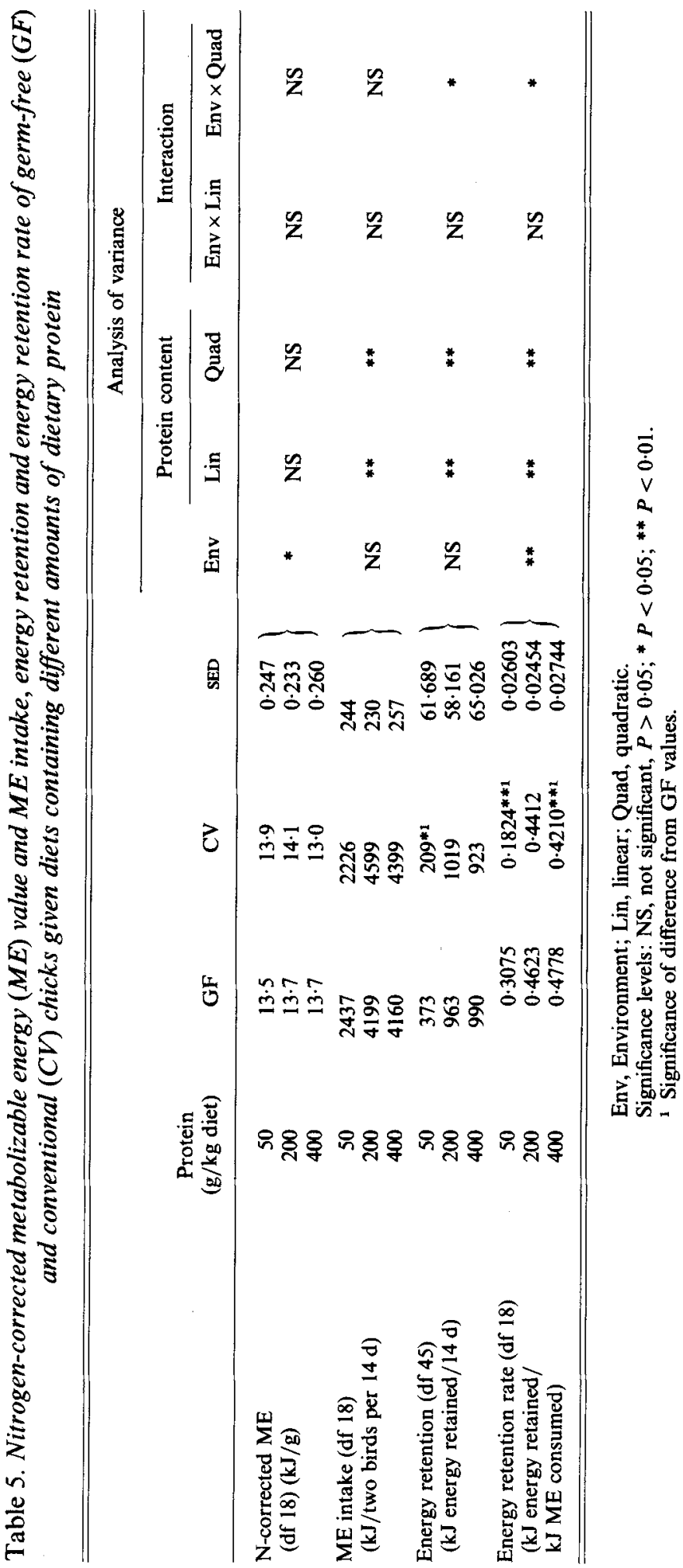


into that required for maintenance, protein deposition and fat deposition gave the following equations:

GF birds:

$$
\mathrm{ME}_{\mathrm{i}}=98.75(\mathrm{SE} 14.14)+1.327(\mathrm{SE} 0.3344) R_{E, f}+1.538(\mathrm{SE} 0 \cdot 1809) R_{E, p}
$$

CV birds:

$$
\mathrm{ME}_{\mathrm{i}}=118.92+1 \cdot 327 R_{E, f}+1 \cdot 538 R_{E, p} \quad(\mathrm{RSD} 19 \cdot 78, \mathrm{df} 23),
$$

where $\mathrm{ME}_{\mathrm{i}}$ is $\mathrm{ME}$ intake and $R_{E, f}$ and $R_{E, p}$ are energy retention as fat and protein respectively, all values being expressed in $\mathrm{kJ} / 24 \mathrm{~h}$ per two birds. Comparisons of residual mean squares due to all the possible regression equations showed that no significant improvement was detected by fitting different regression coefficients, except intercepts, for GF and CV birds and, therefore, the equations above were finally derived. The values of 1.327 and 1.538 for slopes show the ME required to deposit $1 \mathrm{~kJ}$ of fat and protein respectively. The values of 98.75 and 118.92 , for intercepts, are the energy requirements for maintenance for GF and CV birds respectively, and the environmental effect of an elevation by $20 \cdot 17$ (SE 8.01) in the CV state was significant $(P<0.05)$.

\section{DISCUSSION}

Stokstad \& Jukes (1950) found that the growth of chicks was improved by supplementing their diets with antibiotics. GF chicks are generally reported to grow better than their CV counterparts when given a nutritionally adequate diet and comfortable physical conditions (Jayne-Williams \& Fuller, 1971). In the present experiment, body-weight gains of chicks were almost the same between environments, but it was clearly shown that food conversion efficiency in GF chicks was improved compared with that in their CV counterparts. The utilization of dietary protein and energy was therefore investigated from carcass analysis.

Some $\mathrm{N}$ would have been lost while drying the samples by the method used in the present study. However, Shannon \& Brown (1969) compared amounts of N lost on drying poultry excreta using several methods and reported that loss of $\mathrm{N}$ by drying in a forced-air oven at $60^{\circ}$ was less than that obtained using other methods and temperatures. Therefore, it was considered that our method would not seriously affect the conclusions to be drawn. Similarly, carcass $\mathbf{N}$ analysis would also be valid.

Salter et al. (1974) reported that net protein utilization values of good- and poor-quality proteins were not substantially different in GF and CV chicks. Salter (1973) also stated that, with dietary regimens supplying abundant good-quality protein, the gut microflora has only a marginal influence on the protein nutrition of the host. In the present study, an isolated soya-bean protein was used as a protein source, and this is an easily digestible protein (Yokota, 1978). However, protein retention rate was somewhat lower in CV chicks on the $\mathrm{AD}$ and $\mathrm{HD}$, and significantly lower on the LD. This suggests that competition for dietary protein between the host and its gut microflora may occur, so that insufficient protein may be available for the needs of the host, particularly in chicks given the LD.

The body composition of GF birds tended to be higher in fat, which suggests that the conversion of energy into body fat was greater in GF than in CV birds. This difference was clearly larger when chicks were given the diet containing a small amount of protein. When energy costs of protein and fat deposition in GF and CV chicks were calculated, they were not significantly different between environments, and only the energy requirement for maintenance was significantly lower in GF than in $\mathrm{CV}$ chicks $(P<0 \cdot 05)$. The higher energy requirement for maintenance in $\mathrm{CV}$ birds might be explained if (1) the basal metabolic rate (BMR) in CV chicks is higher than that in GF chicks or (2) part of the dietary energy is used or made unavailable by the action of the gut microflora. Assuming that the BMR in 
$\mathrm{GF}$ and $\mathrm{CV}$ birds is similar, then $\mathrm{CV}$ birds required $20 \cdot 17 \mathrm{~kJ} / 24 \mathrm{~h}$ per 2 birds (118.92-98.75) more energy for maintenance than GF birds. This difference was partially accounted for by differences in daily ME intake. ME intakes (kJ/24 h per 2 birds) for GF and $C V$ chicks were 257.04 (18.9 $\mathrm{g}$ food consumed $/ 24 \mathrm{~h}$ per 2 birds) $\times 13.6 \mathrm{~kJ} / \mathrm{g}$ (ME value of GF chicks) and $268.8(19.2 \mathrm{~g}$ food consumed $/ 24 \mathrm{~h}$ per 2 birds $) \times 14.0 \mathrm{~kJ} / \mathrm{g}(\mathrm{ME}$ value of $\mathrm{CV}$ chicks) respectively. In this way CV chicks took in $11 \cdot 76 \mathrm{~kJ}(268 \cdot 8-257.04)$ more than GF chicks from the diet every day. Thus the difference in daily ME intake would account for three-fifths $(11.76 \mathrm{~kJ} / 20.17 \mathrm{~kJ})$ of the difference in energy required for maintenance, but not for all of it. There are four possible reasons that might explain the different utilization of ME between environments. (1) In GF animals the absorption of nutrients would follow digestion by enzymes arising only from the host. In CV animals it would occur after digestion by both the host and the microbial enzymes. Some bacteria may hydrolyse nutrients such as lipid, protein and carbohydrate and produce organic acid (e.g. lactic acid and volatile fatty acids (VFA)). However, Yoshida et al. (1970) showed, in chicks, that availability of energy in fatty acids with a carbon chain shorter than 6 was low, and Bolton \& Dewar (1965) suggested that the fowl obtains only a small amount of energy from acetate. In this way the gut microflora may produce VFA from diets, but they might be unavailable energy sources. (2) ME value is essentially defined as the amount obtained after subtracting the energy in faeces, urine and methane from the gross energy content of a diet. In chickens only small amounts of methane are produced, which are not considered in calculating $\mathrm{ME}$ values. However, some bacteria might produce gases such as $\mathrm{H}_{2}, \mathrm{CO}_{2}$ and methane and small amounts of energy could be lost in those gases by CV chicks. (3) Cellulase and hemicellulase produced by the gut microflora could digest their substrates in the diet. Hegde et al. (1982) reported that the reduction of ME with incorporation of wheat straw into a low-residue diet was less in CV than in GF chicks, and suggested that chicks obtained a small amount of energy from wheat straw by the action of the gut microflora. However, according to Baker (1977), even if hemicellulose were digested by the gut microflora and consequently the ME of the diet were enhanced, birds could not utilize the end-products for their growth. (4) The gut organisms require some $\mathrm{N}$ and energy to support their own activity.

However, the assumption that BMR of GF and CV chicks is similar may not be true. Wostmann et al. (1966) found that GF rats exhaled small amounts of $\mathrm{CO}_{2}$, and their consumption of $\mathrm{O}_{2}$ was $24 \%$ lower than that of CV rats. Levenson et al. (1968) also showed that $\mathrm{O}_{2}$ consumption and $\mathrm{CO}_{2}$ production in GF rats were significantly lower $(15-20 \%)$ than those in CV rats. BMR in relation to microbial environment has not been studied in chicks, and it is possible that the BMR of CV chicks is higher than that of GF chicks, as in rats. However, GF rodents have enlarged caeca compared with $\mathrm{CV}$ rodents. Wostmann et al. (1968) reported that the surgical removal of the enlarged caeca of GF rats increased $\mathrm{O}_{2}$ consumption to a value only slightly lower than that in CV rats. Because there is little difference in the size of caeca in GF and CV chicks, the BMR may not be different between environments. This remains to be examined.

In the present study, a diet of higher energy value (calculated value, $14.8 \mathrm{~kJ} / \mathrm{g}$ ) than that $(12 \cdot 1 \mathrm{~kJ} / \mathrm{g})$ recommended by the (US) National Research Council (1977) was used. Charlet-Lery et al. (1979) reported that, as less energy was used for maintenance when the birds grew more rapidly, the efficiencies of gross energy and ME were higher and the retention of protein was increased. The results reported here suggest that if diets are high in energy, growth rate in birds is not influenced by the gut microflora whatever the concentration of dietary protein. Siddons \& Coates (1972) found that GF birds given a diet of natural ingredients grew significantly better than their corresponding CV controls, whereas no difference in body-weight gain between birds in the two environments was 
observed on a purified diet. We calculated the ME values of their diets from their composition to be about $12.3 \mathrm{~kJ} / \mathrm{g}$ and $15.8 \mathrm{~kJ} / \mathrm{g}$ for the natural and the purified diet respectively. It seems, therefore, that the value of the ratio, energy: protein in the diet, may be important in determining the extent of the growth depression in CV chicks compared with their GF counterparts.

The authors are grateful to Dr M. E. Coates, National Institute for Research in Dairying, England, for her critical reading of the manuscript and to Dr T. Muramatsu, Nagoya University, Japan, for help with the statistical interpretation. They also thank Dr T. Mitsuoka and Mr A. Ozaki, Institute of Physical and Chemical Research, Japan, for irradiation of the experimental diets. This study was supported by a grant-in-aid (no. 00548068) for scientific research from the Ministry of Education, Science and Culture in Japan.

\section{REFERENCES}

Baker, D. H. (1977). Poultry Science 56, 2105-2107.

Bolton, W. \& Dewar, W. A. (1965). British Poultry Science 6, 103-105.

Charlet-Lery, G., Szylit, O. \& Bewa, H. (1979). In Energy Metabolism, pp. 81-84 [L. E. Mount, editor]. London: Butterworths.

Coates, M. E., Ford, J. E., Gregory, M. E. \& Thompson, S. Y. (1969). Laboratory Animals 3, 39-49.

Coates, M. E., Hewitt, D. \& Salter, D. N. (1972). In Germfree Research, pp. 291-295 [J. B. Heneghan, editor]. London: Academic Press.

Fraps, G. S. (1946). Texas Agricultural Experimental Station Bulletin 678, 4-37.

Hegde, S. N., Rolls, B. A. \& Coates, M. E. (1982). British Journal of Nutrition 48, 73-80.

Hill, F. W. \& Anderson, D. L. (1958). Journal of Nutrition 64, 587-603.

Jayne-Williams, D. J. \& Fuller, R. (1971). In Physiology and Biochemistry of the Domestic Fowl, vol. 1, pp. 73-92 [D. J. Bell and B. M. Freeman, editors]. London: Academic Press.

Levenson, S. M., Kan, D., Lev, M. \& Doft, F. (1968). In Advances in Germfree Research and Gnotobiology, pp. 71-75 [M. Miyakawa and T. D. Luckey, editors]. Cleveland: CRC Press.

Levenson, S. M. \& Tennant, B. (1963). Federation Proceedings 22, 109-119.

National Research Council (1977). Nutrient Requirements of Domestic Animals. 1. Nutrient Requirements of Poultry, 7th ed. Washington, DC: National Academy of Science.

Okumura, J., Hewitt, D., Salter, D. N. \& Coates, M. E. (1976). British Journal of Nutrition 36, $265-272$.

Salter, D. N. (1973). Proceedings of the Nutrition Society 32, 65-71.

Salter, D. N., Coates, M. E. \& Hewitt, D. (1974). British Journal of Nutrition 31, 307-318.

Shannon, D. W. F. \& Brown, W. O. (1969). Poultry Science 48, 41-43.

Siddons, R. C. \& Coates, M. E. (1972). British Journal of Nutrition 27, 101-112.

Stokstad, E. L. R. \& Jukes, T. H. (1950). Proceedings of the Society for Experimental Biology and Medicine 73, 523-529.

Wostmann, B. S., Bruckner-Kardoss, E. \& Knight, P. L. (1968). Proceedings of the Society for Experimental Biology and Medicine 128, 137-140.

Wostmann, B. S., Wiech, N. L. \& Kung, E. (1966). Journal of Lipid Research 7, 77-82.

Yokota, H. (1978). Proceedings of XVIth World's Poultry Congress, pp. 1661-1667. Brazil: Sāo Paulo.

Yoshida, M., Morimoto, H. \& Oda, R. (1970). Agricultural and Biological Chemistry 34, 1301-1307. 